\title{
SWOT and AHP Analysis in Determining the Strategy of Product Marketing Excellence in Companies
}

\author{
Siswo Hadi Sumantri ${ }^{1}$, Suyono Thamrin ${ }^{2}$, I Nengah Putra Apriyanto ${ }^{3}$, Edi \\ Suhardono $^{4}$, Beny Rudiawan ${ }^{5}$, Arica Dwi Susanto ${ }^{6}$ \\ ${ }^{12345}$ Indonesia Defense University \\ Sentul, Sukahati, Citeureup, Bogor, West Java, Indonesia 16810 \\ ${ }^{6}$ Indonesian Naval Technology College, STTAL. \\ Bumimoro-Morokrembangan, Surabaya 60187, Indonesia
}

\begin{abstract}
The development of companies in the digital era especially product business in Indonesia is now increasingly prominent in complexity, competition, change, and uncertainty so that the company's marketing and sales systems have not reached a maximal capacity due to the lack of superior and appropriate strategy. The researcher considered several alternatives using SWOT analysis and the Analytical Hierarchy Process (AHP) method to overcome these problems. The results showed that using the SWOT-AHP Analysis, it was found that the Strength parameter got the highest score by $53 \%$ and Opportunity parameter by $21 \%$. Through the SWOT sub-criteria, it was found that the Strenghts priority were S2 (Registered patent) with a score of $0.53, \mathrm{S1}$ (New product) with a score of $0.29, \mathrm{S3}$ (Mechanical technology) with a score of 0.28 , respectively. While weaknesses priority were W2 (inoptimal product promotion) with a score of 0.63 , W1 (product not widely known) with a score of 0.37 . In addition, the Opportunities Priority were the order of $\mathrm{O} 2$ (market share's openness) with a score of $0.52, \mathrm{O3}$ (More efficient products) with a score of 0.29, and 01 (Switching products from manual to automatic) with a score 0.19 . And finally, the Threats priority were T1 (raw material) with a score of 0.53 , $\mathrm{T} 2$ (price competition) with a score of 0.26 and T3 (product fraud) with a score of 0.21 . The top priority of leading marketing strategy are by increasing product quality by $39.3 \%$, while the second priority is marketing cooperation by $21.4 \%$, the third is the pricing strategy by $20.5 \%$ and the last is promotion by $\mathbf{1 4 . 8 \%}$.
\end{abstract}

Keywords: AHP, SWOT, Strategy, Product Marketing, Business.

\section{INTRODUCTION}

The development of companies in the digital era especially product business in Indonesia is now increasingly prominent in complexity, competition, change, and uncertainty especially now that the Digital Age is making competition more complex (Till, 2015). This situation creates a fierce competition between companies, due to the increase of competition, product volumes and the rapid development of digital technology (Pershing, 2006). This forces the company to pay more attention to the environment whether it's internal or external that can affect the development of the company so that the company knows what marketing strategies and how should it can be applied in the company (Hutabarat, 2017).

This paper used some literature to support the research, for example paper with title Strengths, Weaknesses, Opportunities And Threats (SWOT) Analysis On Globacom Ltd (Bello, 2013). Strengths vs Strong Position: Rethinking the Nature of SWOT Analysis (Clardy, 2013). SWOT Analysis of strategic Position of Cycling Federation in Iran (Arefeh Jamshidi, 2012). Comparing AHP and ANP: An Application of Strategic Decisions Making in a Manufacturing Company (GÖRENER, 2012). SWOT Analysis (Lalitha Chavali, 2017). The Strategic Planning (SWOT) Analysis Outcomes And Suggestions According To The Students And The Lecturers Within The Distance Education System (Tugba Yanpar YELKEN, 2012). Coping with Imprecision in Strategic Planning: A Case Study Using Fuzzy SWOT Analysis (Hasan Hosseini-Nasab, 2011). Strategic Planning \& SWOT Analysis (Kotnal, 2017). SWOT Balanced Scorecard (Rangkuti., 2012). Strategic development and SWOT analysis at the University of Warwick (Dyson, 2004). Combining SWOT and AHP Techniques for strategic planning (Osuna \& Aranda, 2007). Prioritiation of e-Govrnment strategies using a SWOTAHP analysis: the case of Turkey (Kahraman, Cetin, \& Demirel, 2007). Studying strategies of sport management using SWOT technique (Leila Asayesh, 2013). Focused SWOT: diagnosing critical strengths and weaknesses (Ronen, 2009). A Synthesis on SWOT Analysis of Public Sector Healthcare Knowledge 
Management Information Systems in Pakistan (Arfan Arshad, 2017). A SWOT Analysis Tool For Indonesian Small and Medium Enterprise (Husni Thamrin, 2017). Development of Strategic Plan for Hotel Industries through Swot Analysis (C.Kiritharan nair, 2016). Importance-Performance Analysis based SWOT analysis (Boonyarat Phadermrod, 2016).

PT. $\mathrm{X}$ is a company that manufactures products for household needs (Sentot Patria. W. S, 2018). This company's marketing system has not reached its maximal capacity due to the lack of an appropriate strategy. This causes sales to not increase as expected. Until recently, the marketing division has made use of technology through websites, social media, digital marketing, mobile friendly, applications, innovation, and also through brochures (Arys Susanto, 2018). In addition, the company instills motto on employees to provide the best service. However, this marketing media cannot be utilized optimally without a good strategy. This study aimed to determine the right marketing strategy and competitiveness by identifying, assessing the company's internal factors and external environment that affect the company.

Based on the existing problems as mentioned above, the best and most appropriate way to determinate product marketing excellence strategy is by considering several alternatives using SWOT analysis and the Analytical Hierarchy Process (AHP) method.

This Paper is organized as follows. Section 2 is review about the basic ship theory. Section 3 would be about the result of the research and section 4 discussion of research. Finally, while in section 5 we would present the conclusions of this paper.

\section{A.. Developmental Strategy}

A.1. Marketing Strategy

Marketing strategy is a way to achieve goals by knowing where we are and what goals will be achieved. The marketing mix is a combination of marketing tools that can be used to affect and retain consumers (Ussahawanitchakit, 2011).
1. Product
2. Price
3. Place
4. Promotion

\section{A.2. Production Strategy}

Production strategy is an effort to manage the use of resources or factors of production such as labor, machinery, equipment, raw materials and so on optimally in the process of transforming raw materials and labor into various products or services (Volkova, 2015).
1. Selection
2. Planning
3. Operation
4. Supervision
5. Renewal

A.3. Operational Strategy
Operational strategy is a vision of operating functions that establishes the overall direction or driving force for decision making. This vision must be integrated with business strategies but not always reflected in formal planning (Pereira, 2015).

1. Capacity and preparations

2. Quality

3. Dissemination

4. Marketing and operations

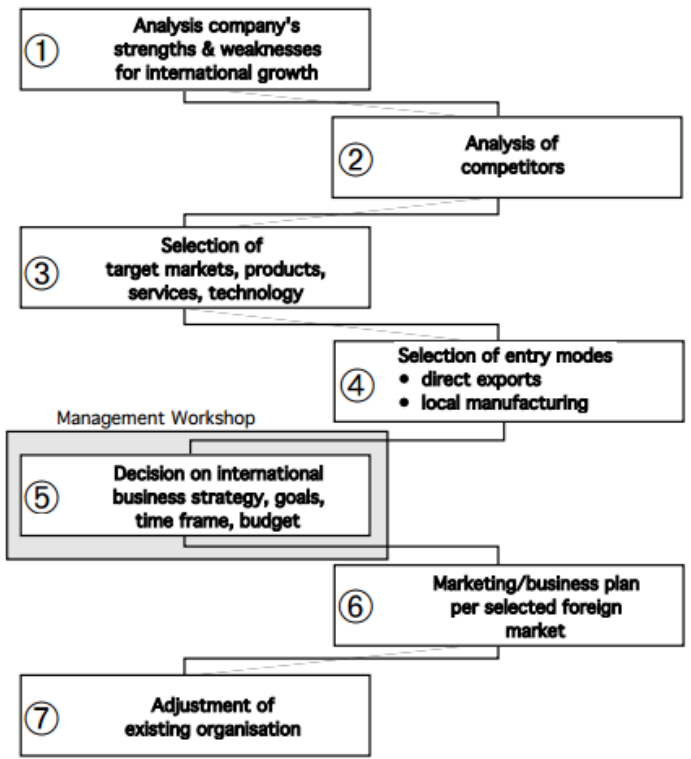

Figure. Steps In The International Business Strategy Formulation Process

\section{B. SWOT Analysis}

SWOT analysis is a strategic planning method used to evaluate strengths, weaknesses, opportunities, and threats in a project or a business speculation (Hajikhani \& Jafari, 2013). These four factors form the acronym SWOT (Strengths, Weaknesses, Opportunities, and Threats). This process involves determining the specific objectives of business or project speculation and identifying internal and external factors that support these goals (Yogi, Rizal, \& Ahmadi, 2017). SWOT analysis can be applied by analyzing and sorting things that affect all four factors, then applying it in the SWOT matrix image, where the application is how strengths are able to take advantage of opportunities, how to overcome weaknesses which prevents advantages from opportunities that exist, then how strengths are able to deal with existing threats, and finally how to overcome weaknesses that can make threats real or create a new threat (Lumaksono, 2014). The hierarchical representation of the SWOT structure is shown in Figure 1 (Chermack \& Kasshanna, 2007).

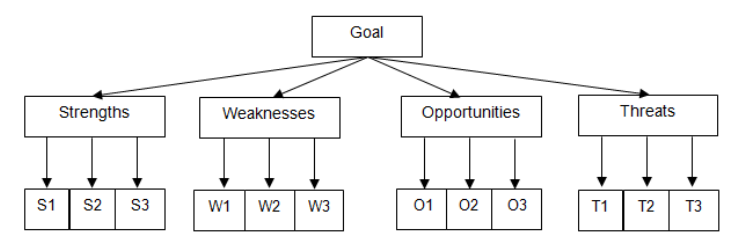


Fig.1. Hierarchical structure of the SWOT matrix

The use of an effective SWOT analysis provides 4 benefits for managers in creating marketing strategies; 1) simplicity: SWOT analysis does not require special training or technical skills; 2) collaboration: because of its simplicity, SWOT analysis encourages collaboration and information exchange between managers from different functional areas; 3) flexibility: it can enhance the quality of organizational strategy planning even without marketing information systems; 4) integration: SWOT analysis can be related to various sources of information (Setiarso, 2018).

To analyze the determination of the strategy to be clear, there are nine types of matrices that can be used namely as follows:

1. Matrix of External Factor Evaluation (EFE)

2. Matrix of Internal Factor Evalution (IFE)

3. Matrix of Competitive Profile (CP)

4. Matrix of SWOT

5. Matrix of Strategic Position and Action Evalution (SPACE)

6. Matrix ofInternal-Exsternal (IE)

7. Matrix of Boston Consulting Group (BCG)

8. Matrix of Grand Strategy

9. Matrix of Quantitative Strategies Planning (QSP)

\section{Analytic Hierarchy Process}

Analytic hierarchy process (AHP) was developed by Thomas L. Saaty in the early 1970s (Saaty, 1980). The AHP method is one of the most popular pairwise comparison methods used for decision making on the Multi-Criteria Decision Making (MCDM) problem (Gorener, Toker, \& Korkmaz, 2012). The AHP approach is designed to help decision makers to combine qualitative and quantitative factors from a complex problem.

The working principle of AHP is to form a problem structure. In solving problems, the AHP method used as a tool to help formulate strategies requires the preparation of hierarchies in the process. The hierarchy in question starts from the Goal, groups of factors, strategic factors and strategic alternatives (Kangas, Pesonen, \& Mikko, 2001).

\section{SWOT-AHP Method}

In this research, the AHP structure obtained from the SWOT matrix and divided into three parts (Devi Cipta Anggraini, 2018). To create a SWOT-AHP based strategic management model, we designed the phases model. Firstly, we identified the SWOT through SWOT analysis, then found external and internal environment that relevated. Secondly modifying factors and third building an evaluation model (Figure 2) (Arica dwi susanto, 2019).

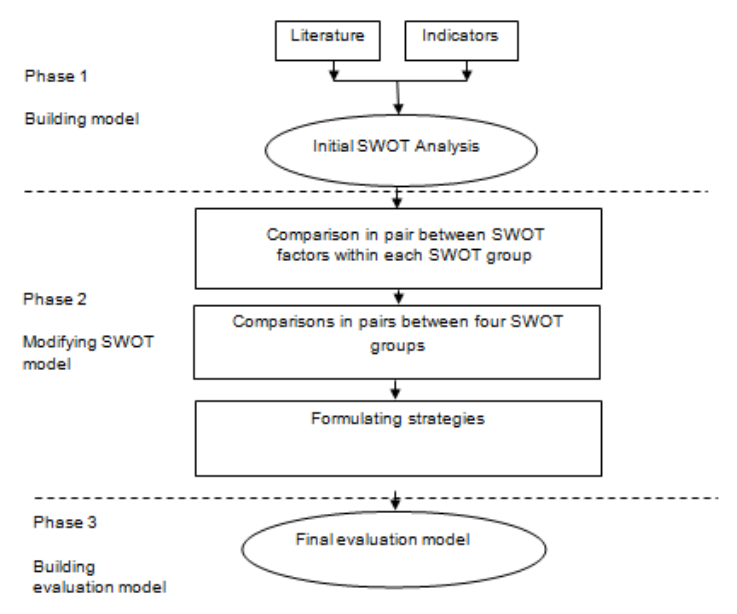

Fig.2. Phases Model

\section{E. Technical Concept}

Data collection methods used were survey methods and direct observation. The data obtained include primary data and secondary data. Primary data were obtained directly from the sample/respondent with a purposive sampling method through interview techniques and assisted with a questionnaire in the form of written questions and alternative answers provided (Hunger \& Wheelen, 2010). Interviews were conducted with the Division Manager of PT. X Industry and marketing operational manager of PT. X Industry. Data collection also used documents provided by companies, especially the PT. X related to the product marketing planning process.

Weighting of internal and external strategic factors and group factors was performed through pairwise comparison methods. After an alternative strategy was created, the AHP method was used to prioritize the alternative. The AHP method produces the best strategy from various alternative strategies recommended through the SWOT matrix (Mehmet, 2011). 


\section{RESULT}

The first step in analyzing SWOT is to make an analysis of internal and external factors from PT. X.

Table 1: SWOT factors and sub-factors for the strategy selection

\begin{tabular}{|l|l|}
\hline Strength (S) & Weakness (W) \\
(S1) New Product & (W1) Product not widely \\
(S2) Registered patent & (W2) Inoptimal product \\
(S3) Mechanical technology & \\
\hline Opportunities (O) & Threats (T) \\
(O1) Switching products from manual to automatic & (T1) Raw Materials \\
(O2) Market share's openness & (T2) Price Competition \\
(O3) More efficient products & (T3) Product Fraud
\end{tabular}

Alternative strategies based on the SWOT factors and sub-factors are developed using the SWOT matrix.

1. Increasing promotion program (A1)

2. Increasing product quality (A2)

3. Pricing strategy (A3)
4. Marketing cooperation (A4)

\section{DISCUSSION}

The next step was pairwise comparison of SWOT factors by using Saaty (1-9) scale. The comparison results are shown in Table 3.

Table 3: Pairwise comparison of SWOT factors

\begin{tabular}{|c|c|c|c|c|c|}
\hline $\begin{array}{c}\text { With Respect To } \\
\text { The Goal }\end{array}$ & Strengths & Weakness & Opportunities & Threats & $\begin{array}{c}\text { Importance Degrees } \\
\text { of SWOT Groups }\end{array}$ \\
\hline Strengths & 1,00 & 5,00 & 3,00 & 3,00 & 3,00 \\
\hline Weaknesses & 0,20 & 1,00 & 0,71 & 0,58 & 0,62 \\
\hline Opportunities & 0,33 & 1,41 & 1,00 & 2,00 & 1,18 \\
\hline Threats & 0,33 & 1,73 & 0,50 & 1,00 & 0,89 \\
\hline
\end{tabular}

$\mathrm{CI}=0,028 \quad \mathrm{CR}=0,03$

Table 4: Geometric mean matrix score of sub-criteria - Alternative expert 1 and expert 2

\begin{tabular}{|c|c|c|c|c|c|c|}
\hline & A1 & A2 & A3 & A4 & Local Weight & Global Weight \\
\hline S1 & 0,17 & 0,15 & 0,25 & 0,36 & 0,140 & 0,072 \\
\hline S2 & 0,12 & 0,32 & 0,14 & 0,42 & 0,528 & 0,273 \\
\hline S3 & 0,18 & 0,17 & 0,27 & 0,36 & 0,333 & 0,172 \\
\hline W1 & 0,13 & 0,15 & 0,29 & 0,43 & 0,500 & 0,043 \\
\hline W2 & 0,10 & 0,25 & 0,21 & 0,41 & 0,500 & 0,043 \\
\hline 01 & 0,12 & 0,23 & 0,20 & 0,40 & 0,250 & 0,055 \\
\hline $\mathbf{O 2}$ & 0,14 & 0,18 & 0,21 & 0,41 & 0,500 & 0,111 \\
\hline $\mathbf{O 3}$ & 0,21 & 0,20 & 0,16 & 0,36 & 0,250 & 0,055 \\
\hline T1 & 0,13 & 0,20 & 0,23 & 0,45 & 0,443 & 0,077 \\
\hline $\mathbf{T 2}$ & 0,12 & 0,16 & 0,18 & 0,47 & 0,387 & 0,067 \\
\hline \multirow[t]{2}{*}{ T3 } & 0,20 & 0,21 & 0,14 & 0,38 & 0,169 & 0,029 \\
\hline & 0,57 & 0,83 & 0,85 & 1,62 & 3,87 & 0,997 \\
\hline Matrix Score & 0,148 & 0,207 & 0,214 & 0,393 & 0,961 & \\
\hline
\end{tabular}

Based on the calculation of the geometric mean, it is found that the first priority is on improving product quality (0.393), the second is marketing cooperation (0.214), the third priority is pricing strategy $(0.207)$ and the last is promotion (0.148).

\section{CONCLUSION}

The results showed that the SWOT-AHP analysis on the formulation of superior product marketing strategies stated that the most important priority strategies is the Strength-Opportunity strategy. Strength got the highest score of 53\% and Opportunity by $21 \%$. The SO strategy focuses on the strengths the company has to seize the opportunities. Through the SWOT sub-criteria, it was found that the Strenghts priority were S2 (Registered patent) with a score of 0.53 , S1 (New product) with a score of $0.29, \mathrm{~S} 3$ (Mechanical technology) with a score of 0.28 , respectively. While weaknesses priority were W2 (inoptimal product promotion) with a score of $0.63, \mathrm{~W} 1$ (product not widely known) with a score of 0.37 . In addition, the Opportunities Priority were the order of $\mathrm{O} 2$ (market share's openness) with a score of $0.52, \mathrm{O} 3$ (More efficient products) with a score of 0.29 , and $\mathrm{O} 1$ 
(Switching products from manual to automatic) with a score 0.19 . And finally, the Threats priority were T1 (raw material) with a score of 0.53 , T2 (price competition) with a score of 0.26 and $\mathrm{T} 3$ (product fraud) with a score of 0.21 .. Based on the alternative selection results on the formulation of a marketing strategy for electric battery sprayer knapsack products, it can be concluded thatthe main priority are increasing product quality by $39.3 \%$, the second priority were marketing cooperation with a score of $21.4 \%$, the third is pricing strategies by $20.5 \%$ and finally the promotion by $14.8 \%$.

\section{ACKNOWLEDGEMENTS}

This research had been Supported by Indonesia Defense University and Indonesia Naval Technology College (STTAL).

\section{REFERENCES}

Arefeh Jamshidi, S. N. (2012). SWOT Analysis of strategic Position of Cycling Federation in Iran. International Journal of Academic Research in Business and Social Sciences , 2 (5), 106-113.

Arfan Arshad, M. F. (2017). A Synthesis on SWOT Analysis of Public Sector Healthcare Knowledge Management Information Systems in Pakistan. (IJACSA) International Journal of Advanced Computer Science and Applications , 8 (8), 131-136.

Arica dwi susanto, N. S. (2019). Business Development Strategy Analysis PT. X Using the SWOT Method. International Journal of Academic and Applied Research (IJAAR) , 4-9.

Arys Susanto, A. D. (2018). Optimization of the ANP and Set Covering Method for the Allocation of Tanker in the East Sea Region of Indonesia. International Journal of ASRO-STTAL , 63-74.

Bello, N. A. (2013). Strengths, Weaknesses, Opportunities And Threats (SWOT) Analysis On Globacom Ltd. International Journal of Information Technology and Business Management , 16 (1), 83-91.

Boonyarat Phadermrod, R. M. (2016). ImportancePerformance Analysis based SWOT analysis. International Journal of Information Management , 134.

C.Kiritharan nair, P. (2016). Development of Strategic Plan for Hotel Industries through Swot Analysis. SSRG International Journal of Mechanical Engineering (SSRG-IJME) , 3 (3), 6-10.

Chermack, T. J., \& Kasshanna, B. K. ( 2007). The use and misuse of SWOT analysis and implications for HRD professionals. Human Resource Development International , 383-399.

Clardy, A. (2013). Strengths vs. Strong Position: Rethinking the Nature of SWOT Analysis. Modern Management Science \& Engineering , 1 (1), 100-122.
Devi Cipta Anggraini, S. A. (2018). Implementation of SWOT-ANP Method to Determine the Best Strategy on Development Women Navy Resources in Indonesia War Ship. International Journal of Academic Multidisciplinary Research (IJAMR), 11-20.

Dyson, R. G. (2004). Strategic development and SWOT analysis at the University of Warwick. European Journal of Operaional Research , 631-640.

GÖRENER, A. (2012). Comparing AHP and ANP: An Application of Strategic Decisions Making in a Manufacturing Company. International Journal of Business and Social Science , 3 (11), 194-208.

Gorener, A., Toker, K., \& Korkmaz. (2012). Application of Combined SWOT and AHP : A Case Study for a Manufactruring Firm. Procedia - Social and Behavioral Science , 1525-1534.

Hajikhani, A., \& Jafari, H. R. (2013). Developing a Mix Method of a SWOT, BSC and QFD toward strategic Planning. Interdisciplinary Journal of Contemporary Research in Business , 476-489.

Hasan Hosseini-Nasab, A. H.-N. (2011). Coping with Imprecision in Strategic Planning: A Case Study Using Fuzzy SWOT Analysis. iBusiness , 3, 23-29.

Hunger, J. D., \& Wheelen, T. L. (2010). Essentials Of Strategic Management 5th edition. United States of Amerika: Prentice Hall.

Husni Thamrin, R. H. (2017). A SWOT Analysis Tool For Indonesian Small and Medium Enterprise. ARPN Journal of Engineering and Applied Sciences , 12 (2), 620-625.

Hutabarat, L. F. (2017). Indonesian Female Peacekeepers in the United Nations Peacekeeping Mission. Jurnal Pertahanan , 185-206.

Kahraman, C., Cetin, N., \& Demirel, T. (2007). Prioritiation of e-Govrnment strategies using a SWOTAHP analysis: the case of Turkey. European Journal of Information System , 284-298.

Kangas, J., Pesonen, M., \& Mikko. (2001). A'WOT:Integrating the AHP with SWOT analysis. ISAHP , 189-197.

Kotnal, J. R. (2017). Strategic Planning \& SWOT Analysis. International Journal of Advanced Research and Development , 2 (6), 60-62.

Lalitha Chavali, D. P. (2017). Swot Analysis. International Journal of Management and Applied Science, 3 (4), 50-51.

Leila Asayesh, H. K. (2013). Studying strategies of sport management using SWOT technique. European Journal of Experimental Biology , 3 (6), 54-60.

Lumaksono, H. (2014). Implementation of SWOTFAHP method to determine the best strategy on development of traditional shipyard in sumenep. Academic research international, 56-67. 
Mehmet, E. (2011). A Fuzzy Multi-criteria SWOT Analysis: An application to nuclear power plant site selection. International Journal of Computational Intelligence Systems , 583-595.

Oreski, D. (2012). Strategy development by using SWOT - AHP. TEM Journal , 1 (4), 283-291.

Oreski, D. (2012). Strategy development by using SWOT-AHP. TEM Journal , 283-291.

Osuna, E. E., \& Aranda, A. (2007). Combining SWOT and AHP Techniques for strategic planning. ISAHP , 18.

Pereira, C. S. (2015). Pereira Diamond: Benefits Management Framework. The International Journal of Business \& Management, 3 (3), 47-56.

Pershing, J. A. (2006). Handbook of Human Performance Technology. San Fransisco: Pfeiffer.

Rangkuti., F. (2012). SWOT Balanced Scorecard. Jakarta: PT Gramedia.

Ronen, A. C. (2009). Focused SWOT: diagnosing critical strengths and weaknesses. International Journal of Production Research , 47 (20), 5677-5689.

Saaty, T. (1980). The Analytical Hierarchy Process. New York: McGraw-Hill.

Sentot Patria. W. S, A. D. (2018). Performance Assessment of PT. X Automotive Companies Using Performance Prism and Analytical Hierarchy Process
(AHP). SSRG International Journal of Economics and Management Studies (SSRG-IJEMS) , 11-18.

Setiarso, B. (2018). Determination of landing beach location for amphibious operations on the west papua sea with Analytic Hierarchy Process (AHP):case study on Sorong regency. Journal Of Defense Resources Management, 21-33.

Till, G. (2015). Indonesia as a growing maritime power: possible implications for Australia. Soundings Sea Power Centre , 1-13.

Tugba Yanpar YELKEN, F. K. (2012). The Strategic Planning (SWOT) Analysis Outcomes And Suggestions According to The Students And The Lecturers Within The Distance Education System. Turkish Online Journal of Distance Education , 13 (2), 267-276.

Ussahawanitchakit, P. P. (2011). Strategic Entrepreneurship Management Competency And Firm Success: A Comparative Study of SMEs in Auto And Electronic Parts in Thailand. International Journal of Business Strategy, 11 (2), 1-31.

Volkova, R. M. (2015). Strategic Innovation Application in Creative. Journal of Business Management (10), 15-27.

Yogi, P., Rizal, O., \& Ahmadi. (2017). Feasibility Analysis of Naval Base Relocation using SWOT and AHP method to support main duties operation. Journal of Defense management, 14-30.

\section{Creative Commons Attribution License 4.0 (Attribution 4.0 International, CC BY 4.0)}

This article is published under the terms of the Creative Commons Attribution License 4.0 https://creativecommons.org/licenses/by/4.0/deed.en_US 